\title{
JNPH
}

Volume 7 No. 1 (April 2019)

(C) The Author(s) 2019

\section{ANALISIS KANDUNGAN ZAT PENGAWET PADA JAJANAN BAKSO \\ DI SEKOLAH DASAR WILAYAH KECAMATAN RATU AGUNG KOTA BENGKULU}

\section{A PRESERVATIVE INGREDIENTS ANALYSIS ON HAWKER MEATBALLS IN PRIMARY SCHOOL THE SUB-DISTRICT OF QUEEN AGUNG THE CITY OF BENGKULU}

\author{
HAIDINA ALI , MELY GUSTINA \\ POLTEKKES KEMENKES BENGKULU \\ Email: alimanafh@gmail.com
}

\begin{abstract}
ABSTRAK
Latar Belakang: Boraks merupakan senyawa yang bisa memperbaiki tekstur makanan sehingga menghasilkan rupa yang bagus, misalnya bakso, kerupuk bahkan mie basah yang berada di pasaran.Formalin merupakan bahan beracun dan berbahaya bagi kesehatan manusia. Selain itu, kandungan formalin yang tinggi dalam tubuh juga menyebabkan iritasi lambung, alergi, bersifat karsinogenik (menyebabkan kanker) dan bersifat mutagen. Tujuan penelitian ini adalah untuk mengetahui analisis kandungan zat pengawet boraks dan formalin pada jajanan bakso di sekolah dasar wilayah Kecamatan Ratu Agung Kota Bengkulu. Metode: Jenis penelitian ini adalah penelitian deskriptif, dengan pemeriksaan kandungan terdapat 64 sampel pada jajanan bakso yang dijual pada pedagang sekolah dasar wilayah Kecamatan Ratu Agung Kota Bengkulu dengan metode uji kandungan dengan menggunakan Test Kit Boraks Chemkit dan Formaldehyde Test Kit. Hasil: Hasil penelitian boraks didapat 1 sampel positif $(+)$ mengandung boraks pada bakso dan 1 sampel positif $(+)$ mengandung formalin pada bakso. Pedagang bakso di sekolah dasar wilayah Kecamatan Ratu Agung Kota Bengkulu 30 sampel negatif tidak menggunakan zat pengawet pada boraks dan formalin. Saran: Saran kepada masyarakat diharapkan dapat berhati-hati dalam memilih jajanan dalam hal ini terutama bakso. Pilihlah bakso yang tidak terlalu kenyal dan miliki warna putih yang tidak tersebar lalat.
\end{abstract}

\section{Kata Kunci : Kandungan Zat pengawet Pada Jajanan Bakso}

\begin{abstract}
The background of: Borax is a compound which can fix the texture of food so as to an extent that is good, for example meatballs, crackers even particulary noodles that they are located in the market. Formalin is toxic materials and dangerous to human health.In addition, the womb formalin high in the body well cause irritation stomach, allergic, is carcinogenic (cause cancer) and was in nature mutegen. The purpose of this research is to know the ingredients preservative borax and formalin in hawker meatballs in primary school queen regal sub district in bengkulu city. Method: The kind of research this is the descriptive, there are 32 examining the samples to hawker meatballs traders sold at primary school queen regal sub district in bengkulu city the method used to test the womb using Test Kit Chemkit and Formaldehyde Test Kit. Results: The
\end{abstract}


results of the study borax there are 1 in the entire household sample showed signs of positive sentiments $(+)$ containing borax delicious and 1 in the entire household sample showed signs of positive sentiments $(+)$ containing formalin in meatballs. A meatball seller in primary school the sub district of queen regal the city of bengkulu 30 in the entire household sample negatuf do not use a substance a preservative on borax and formalin. Advice:Advice to people should be berhati-hati in choosing snacks in this especially meatballs. Pilihlag meatballs are not too spongy and have not spread white files.

\section{Keywords: A Preservative Ingredients on Hawker Meatballs}

\section{PENDAHULUAN}

Pangan jajanan merupakan makanan yang di jual oleh pedagang kaki lima di kantin, di jalanan dan tempat-tempat lain sejenisnya. Pangan jajanan anak umumnya di temukan di lingkungan sekolah dan secara rutin dikonsumsi oleh sebagaian besar anak sekolah (Ghaisani, 2015).

Makanan merupakan kebutuhan pokok manusia karena didalamnya mengandung nutrisi yang diperlukan oleh tubuh. Terkadang untuk memenuhi kebutuhan makanan, manusia/konsumen tidak hanya membutuhkan makanan pokok seperti nasi dengan lauk pauknya. Terutama anaka-anak di Sekolah Dasar (SD), terkadang mereka lebih cenderung memilih makanan instan seperti pangan jajanan untuk memenuhi kebutuhannya. Pangan jajanan menurut Food and agriculture Organization (FAO) didefinisikan sebagai makanan dan minuman yang dipersiapkan atau dijual oleh pedagang kaki lima dan tempat-tempat keramaian umum lain yang bisa lasung dimakan atau dikonsumsi tanpa pengolahan atau persiapan lebih lanjut (Nasution, 2009).

Boraks merupakan kristal lunak yang mengandung unsur boron, berwarna putih, tidak berbau serta stabil pada suhu dan tekanan normal. Boraks mudah larut dalam air dan tidak larut dalam alkohol. Boraks merupakan senyawa yang bisa memperbaiki tekstur makanan sehingga menghasilkan rupa yang bagus, misalnya bakso, kerupuk bahkan mie basah yang berada di pasaran (Rahmawati, 2010). Boraks adalah zat pengawet yang banyak digunakan dalam industri pembuatan taksidermi, insektarium dan herbarium, tapi dewasa ini boraks cenderung digunakan dalam industri rumah tangga sebagai bahan pengawet makanan seperti pada pembuatan mie dan bakso (Tumbel, 2010).

Formalin bukanlah bahan tambahan makanan, bahkan formalin tidak boleh ditambahkan pada makanan. Memang orang yang mengkonsumsi makanan yang berformalin dalam beberapa kali saja belum merasakan akibatnya. Tapi efek dari bahan pangan makanan berformalin bisa dirasakan setelah beberapa tahun kemudian. Pemakaian formalin pada makanan dapat mengakibatkan keracunan pada tubuh manusia, yaitu rasa sakit perut yang akan disertai muntahmuntah, sakit kepala, kejang, tidak sadar hingga koma, selain itu juga dapat terjadinya kerusakan pada system susunan saraf pusat dan ginjal (Effendi, 2009).

\section{METODE PENELITIAN}

Jenis penelitian ini adalah penelitian deskriptif cara melakukan pengambilan sampel pada penjual bakso yang dijual di SD Wilayah Kecamatan Ratu Agung Kota Bengkulu dan selanjutnya dilaksanakan pemeriksaan kandungan zat pengawet boraks dan formalin. Populasi sejumlah 32 dengan menggunakan total sampling.

\section{HASIL PENELITIAN}

\section{Analisis univariat}

Analisis univariat bertujuan untuk menjelaskan atau mendeskripsikan karakteristik variabel peneitian. Pada 
umumnya dalam analisa ini hanya menghasilkan disribusi frekuensi dan persentase dari tiap variabel. Berdasarkan hasil penelitian uji kandungan zat pengawet boraks dan formalin pada jajanan bakso yang dijual sekolah dasar menggunakan tabel hasil sebagian berikut.

Tabel 1 Hasil Distribusi Frekuensi Uji Kandungan Zat Pengawet Boraks Pada Jajanan Bakso Sekolah Dasar Wilayah Kecamatan Ratu Agung Kota Bengkulu

\begin{tabular}{cccc}
\hline No & Hasil Sampel & Jumlah & \% \\
\hline 1 & $\begin{array}{c}\text { Positif mengandung zat } \\
\text { pengawet boraks }\end{array}$ & 1 & $3,1 \% \%$ \\
\hline 2 & $\begin{array}{c}\text { Negatif mengandung zat } \\
\text { pengawet boraks }\end{array}$ & 31 & $96,9 \%$ \\
\hline Jumlah & 32 & $100 \%$ \\
\hline
\end{tabular}

Berdasarkan tabel 1 dapat disimpulkan bahwa hampir sebagian kecil $(3,1 \%)$ hasil uji kualitatif boraks pada bakso positif $(+)$ mengandung boraks dan sebagian besar $(96,9 \%)$ negatif mengandung zat pengawet boraks.

Tabel 2 Hasil Distribusi Frekuesi Uji Kandungan Formalin Pada Jajanan Bakso Sekolah Dasar Wilayah Kecamatan Ratu Agung Kota Bengkulu

\begin{tabular}{cccc}
\hline No & Hasil Sampel & Jumlah & \% \\
\hline 1 & $\begin{array}{c}\text { Positif mengandung zat } \\
\text { pengawet formalin }\end{array}$ & 1 & $3,1 \%$ \\
\cline { 1 - 3 } 2 & $\begin{array}{c}\text { Negatif mengandung zat } \\
\text { pengawet formalin }\end{array}$ & 31 & $96,9 \%$ \\
\cline { 1 - 2 } & Jumlah & 32 & $100 \%$ \\
\hline
\end{tabular}

Berdasarkan tabel 2 dapat disimpulkan bahwa hampir sebagian kecil $(3,1 \%)$ hasil uji kualitatif boraks pada bakso positif $(+)$ mengandung formalin dan sebagian besar (96,9\%) negatif mengandung zat pengawet formalin

\section{PEMBAHASAN}

\section{Pemeriksaan Boraks}

Bakso yang memiliki tekstur kenyal memang lebih banyak diminati oleh masyarakat. Kekenyalan tersebut dikarenakan dominanya daging sapi, ikan, dan ayam dalam adonan. Tetapi beberapa pedagang menggantikan kekenyalan tersebut dengan BTP pengeyal yang dilarang penggunaannya oleh pemerintah, yaitu boraks.

Pada penelitian yang telah dilakukan sesuai prosedur kerja yang baik. Metode yang digunakan yaitu colorimetri (Test Kit Chemkit), sampel ditimbang sebanyak 2,5 gram lalu dilarutkan dalam Aquadest sebanyak $10 \mathrm{ml}$ kemudian haluskan sampel dengan menggunakan mortal dan pastel setelah itu masukan sampel kedalam tabung reaksi sebanyak $5 \mathrm{ml}$ selanjutkan teteskan reagen pereaksi I sebanyak 2, tambahan reagen pereaksi II sebanyak 3 tetes ambil kertas uji Chemkit dan celupkan ujungnya ke dalam reagen yang sudah di campur, dan angin-anginkan kertas uji chemkit dan biarkan selama 5 menit jika hasil positif mengandungzat pengawet boraks akan terjadi perubahan warna merah bata.

Berdasarkan tabel 1 diatas sampel yang digunakan pada penelitian ini adalah jajanan bakso yang dijual oleh pedagang sekolah dasar wilayah Kecamatan Ratu Agung Kota Bengkulu. 1 Sampel positif mengandung zat pengawet boraks terdapat pada Sekolah Dasar Negeri 49 yaitu sebagian kecil (3,1\%) pedagang bakso yang dihasilkan pada sampel berubah menjadi warna merah bata dan sampel yang tidak mengandung zat pengawet boraks yaitu ada sebagian besar (96,9\%) negatif 31 sampel.

Boraks adalah bahan berbahaya yang akana terakumulasi dalam tubuh dan menyebabkan gangguan kesehatan. Kadar fatal yang dapat menyebabkan kematian pada orang dewasa dapat terjadi dalam dosis 15-25 gram, sedangkan pada anak dosis 5-6 gram (Cahyadi, 2009).

Dari hasil penelitian, ternyata masih ada 
pangan jajanan bterutama bakso yang dijual di beberapa SD Wilayah Kecamatan Ratu Agug Kota Bengkulu mengandung boraks. Walaupun kadar yang terkandung masih dalam jumlah kecil tetapi tetap saja hal ini berbahaya untuk konsumennya, mengingat Permenkes RI No. 1168/Menkes/IX/1999 yang menyatakan bahwa boraks merupakan BTP yang dilarang penggunaannya dalam makanan. Memang gejala keracunan boraks tidak dapat langsung dirasakan karena sifatnya yang akumulatif (tertimbun). Artinya dampak keracuan boraks dapat timbul saat tubuh jenuh oleh racun yang telah manumpuk. Dan organ yang paling berpengaruh dalam hal ini adalah ginjal karena pada organ tersebut merupakan tempat sisa metabolisme dieksresi (Jansen, 2010).

\section{Pemeriksaan Formalin}

Berdasarkan hasil penelitian yang telah dilakukan sesuai prosedur kerja yang baik. Metode yang digunakan yaitu colorimetri (Formaldehyde Test Kit), sampel ditimbang sebanyak 2,5 gram lalu dilarutkan dalam Aquadest sebanyak $10 \mathrm{ml}$ kemudian haluskan sampel dengan menggunakan mortal dan pastel setelah itu masukan sampel kedalam tabung reaksi sebanyak $5 \mathrm{ml}$ selanjutkan teteskan reagenA sebanyak 4 tetes dan reagen $\mathrm{B} 4$ tetes tunggu selama 5 menit jika hasil positif mengandung zat pengawet formalin akan terjadi perubahan warna ungu.

Berdasarkan tabel 2 diatas sampel yang digunakan pada penelitian ini adalah jajanan bakso yang dijual oleh pedagang sekolah dasar wilayah Kecamatan Ratu Agung Kota Bengkulu. 1 Sampel positif mengandung zat pengawet formalin terdapat pada Sekolah Dasar Negeri 32 yaitu sebagian kecil $(3,1 \%)$ pedagang bakso yang dihasilkan pada sampel berubah menjadi warna ungu dan sampel yang tidak mengandung zat pengawet formalin yaitu ada sebagian besar (96,9\%) negatif 31 sampel.

Formalin dilarang pengunaannya dalam makanan berdasarkan Permkes RI No
722/Menkes/Per/1988, tentang tambahan makanan yang meliputi anti oksidan, anti kempal, pengatur keasaman, pemanis buatan, pemutih, dan pematang tepung, pengawet dan lain-lain. Adapun pengunaan hidrogen peroksi pada produk pangan makanan juga dilarang oleh pemerintah berdasarkan Peraturan Menteri Kesehatan No 033 Tahun 2012 tentang (BMP) Bahan Makanan Pangan.

Formalin merupakan bahan beracun dan berbahaya bagi kesehatan manusia. Formalin sangat berbahaya bila terhirup, mengenai kulit dan tertelan. Akibat yang ditimbulkan dapat berupa luka bakar pada kulit,iritasi pada saluran penafasan, reaksi alergi dan membahayakan manusia. Dampak formalin pada kesehatan manusia yaitu dapat bersifat akut, kronik dan apabila terhirup dalam jangka waktu lama maka akan menimbulkan sakit kepala gangguan pernafasan, batukbatuk, radang selaput lender hidung, dan mual-mual.

\section{KESIMPULAN}

Berdasarkan hasil penelitian yang telah dilakukan di sekolah dasar wilayah Kecamatan Ratu Agung Kota Bengkulu dan pemeriksaan di laboratorium Poltekkes Kemenkes Bengkulu dapat disimpulkan bahwa :

1. Dari hasil uji kandungan zat pengawet boraks dan formalin ada 32 asampel terdapat 1 sampel positif $(+)$ menganung boraks pada bakso dan sampel positif $(+)$ mengandung formalin pada bakso.

2. 30 sampel negatif mengandung zat pengawet boraks dan formalin pada jajanan bakso.

\section{SARAN}

1. Bagi Institusi Pendidikan Akademik

Dapat dijadikan sebagai bahan pembelajaran mahasiswa Jurusan Kesehatan Lingkungan khususnya mata kuliah Penyehatan Makanan dan Minuman tentang kandungan zat 
pengawet pada makanan.

2. Bagi Masyarakat dan Pedagang

a. Kepada masyarakat diharapkan dapat berhati-hati dalam memilih jajanan dalam hal ini terutama bakso. Pilihlah bakso yang tidak terlalu kenyal dan miliki warna putih yang tidak tersebar lalat.

b. Diharapkan bagi pedagang tahu tentang dampak dan pengaruh jika mengkonsumsi zat pengawet yang dilarang karena dapat membahayakan kesehatan sehingga pedagang menjual makanan yang aman untuk dikonsumsi.

3. Kepada departemen kesehatan agar lebih meningkatkan pengawasan terhadap penggunaan bahan tambahan makanan yang dilakukan pengolah makanan seperti bakso.

4. Bagi Peneliti Lain

Dapat dijadikan sebagai bahan makanan kepada penelitian selanjutnya dalam meneliti masalah bakso.

\section{DAFTAR PUSTAKA}

Cahyad W, 2008. Bahan Tambahan Pangan, Jakarta: Erlangga

Ghaisani, 2015. Akar Masalah Keamanan Pangan Jajanan Anak Sekolah (PJAS): Studi Kasus Pada Bakso, Makanan Ringan, Dan Mi. Skripsi Fakultas Teknologi Pertanian Bogor.

Nasution, Anisyah. 2009. Analisis kandungan Boraks Pada Lontong Di Kelurahan

Padang Bulan Kota Medan Tahun 2009. Skripsi. Medan: Universitas Sumatera Utara.

Tumbel, M. 2010. Analisis Kandungan Boraks dalam Mie Basah yang Beredar di Kota Makassar.

Effendi. 2009 dalam Mahdi, C. 2012. Mengenal Bahaya Formalin, Boraks, dan Pewarna Berbahaya dalam Makanan. FMIPA-UB. 